\title{
Influence of herbicides under biofertilizer application on fennel (Foeniculum vulgare) yield and quality with special reference to herbicide residues
}

\author{
Ibrahim Abdallah ${ }^{{ }^{*}}\left(\mathbb{D}\right.$, Alia Amer ${ }^{2}$ and Dalia El-Hefny ${ }^{3}$
}

\begin{abstract}
Background: Weed occurrence and fertilization are considered two of the most factors influencing fennel yield. A two season's field study was undertaken to investigate the response of fennel crop to two different herbicides under the application of biofertilizers. The two herbicides are pendimethalin (at reduced rate), fluazifop-p butyl and a combination of sequential application of both of them. The biofertilizers were used in 3 rates of 1:1:1, 2:1:1 and 1:1:2( $(\mathrm{v} / \mathrm{v} / \mathrm{v})$ from atmospheric nitrogen-fixating, phosphorous-dissolving and potassium-solubilizing bacterial strains.

Results: The results indicated that under all rates of the biofertilizers, the two herbicides applied individually caused significant reduction in growth parameters of the fennel plant estimated. Hand weeding (untreated check) increased fruit yield by $63 \%$ and oil yield by $78 \%$ compared to unweeded control, while sequential application of pendimethalin + fluazifop increased fruit yield by $45 \%$ and oil yield by $83 \%$ under biofertilizers at the rate of 2:1:1. Slight decrease in protein content using pendimethalin + fluazifop (12.94, and 12.96\%) compared to $13.56 \%$ for hand weeding was observed. However, fluazifop alone showed no significant differences (13.63 and 13.13\%) during both seasons under the biofertilizer rate of 2:1:1. No detectable residues of pendimethalin and fluazifop applied alone or sequentially were found in the analyzed dry seeds.
\end{abstract}

Conclusion: The obtained results concluded that using proper level of biofertilizer combined with herbicides would increase the seed yield and oil content of fennel. Nevertheless, further investigation is needed to search for safer and effective weed control methods in medicinal plants.

Keywords: Fennel, Biofertilizers, Pendimethalin, Fluazifop, Herbicide residues

\section{Background}

Fennel (Foeniculum vulgare Mill) is one of the important seed spice crops. It is a perennial hardy herb and a high value cash crop that grow in middle Egypt (Ehsanipour et al. 2012). The profitable value of this crop is linked principally to the fruits which contain volatile and fixed oil. Fennel is used in several purposes as an appetite

\footnotetext{
*Correspondence: isabdallah@agr.cu.edu.eg

${ }^{1}$ Pesticides Department, Faculty of Agriculture, Cairo University, Giza,

Egypt

Full list of author information is available at the end of the article
}

stimulant, diuretic, carminative, flavoring agents, stomachic, estrogenic activities, essence in cosmetics and perfumery, antioxidant, antimicrobial, anti-inflammatory, antidiarrheic, antispasmodic, hepatoprotective, lactation promoter and treatment of nervous disturbances (Singh et al. 2006; Gori et al. 2012; Abdel-Rahman and AbdelKader 2020). According to Bird et al. (2003), the soil fertility and weed management are often considered two of the most critical management factors impacting crop yield. Biofertilizers, as an alternative for chemical alternatives, have significant role in fixing atmospheric nitrogen and in phosphorous solubilization. They also help in 
stimulating the plant growth hormones providing better nutrient uptake and increased tolerance toward drought and moisture stress (Haggag et al. 2014). Several studies and reports pointed out that fennel responded to biofertilizers by increasing growth and oil yield and changing its chemical composition, Badran and Safwat (2004), ElGhadban et al. (2006), Mahfouz and Sharaf-Eldin (2007) and Ibrahim et al. (2020). In addition, fennel generally takes longer time for germination and also has slow initial growth which often leads to heavy infestation of weeds. If not controlled timely, weeds adversely affect the growth and cause substantial loss in yields which found to be as high as $91.4 \%$ as reported by Mali and Suwalka (1987). Weeds can also affect quality of the essential oils content (Wall and Friesen 1986; Zheljazkov and Zhalnov 1995). Both quantitative and qualitative yield losses due to weed infestation have been largely studied in field and vegetable crops. However, research on this subject in medicinal plants (e.g., fennel) is limited due to some very specific features of these crops. In addition, the aspects concerning quality issues are even less studied. Mechanical and cultural weed control means are shown to be less effective and expensive, especially at periods of labor shortage and higher cost. These methods also deplete soil water supply and nutrients absorbed by the infested weeds. Chemical control using herbicides is mostly favored as they offer efficient, cost-effective and reliable weed control contributing to high seed yields. Herbicides are generally providing a threefold to fourfold economic return compared to other weed control measures (Ngow et al. 2020). Studies have shown that herbicide application effectively controls the weeds and can increase the seed yield by 43.2 to $86.9 \%$ (Voevodin and Borisenko 1981 and Patel et al. 2017). Fluazifop-p-butyl and pendimethalin are among the major herbicides commonly used for weed control. Fluazifop is a selective post-emergence herbicide for the control of annual and some perennial grass weeds in various broadleaf field and vegetable crops. Pendimethalin is a selective pre-emergence herbicide used to control annual grasses and broadleaf weeds on a variety of agricultural crops. However, in Egypt, limited information is available on registered herbicides for weed control and their residues in medicinal and aromatic plants. Consequently, monitoring of herbicide residues should also include medicinal and aromatic plants. Moreover, little attention has been paid to evaluate the effects of either herbicides or weeds on the various fennel traits that contribute to crop quality. Besides, information on the interactive effect of both herbicides and biofertilizers application is needed for developing effective weed management and better crop production in fennel. Therefore, the main objectives of this work were to: (1) investigate the influence of the interaction of the two selected herbicides and the biofertilizers on growth of fennel plants, fruit/seed yield and seed oil quality; (2) determine herbicide residues in the fruits at the harvest time to protect food consumers from adverse effects may occur.

\section{Methods}

Plant materials and experimental assay

A field study was conducted at the Farm of Medicinal and Aromatic Plants Research Department, El-Kanater El-Khairiya, Qalyubia Governorate, Egypt, “ $30^{\circ} 19^{\prime} \mathrm{N}$, $31^{\circ} 13^{\prime} \mathrm{E}, 16.9 \mathrm{~m}$ above sea level rise" on 25th and 30th of October of the first and the second seasons, respectively. Physical and chemical properties of the experimental soil are shown in Table 1, and the analysis was done at Soil, Water and Environmental Institute Lab. Agricultural Research Center (A.R.C.) as described by Donald (1996). Fennel fruits were obtained from the Medicinal and Aromatic Plants Department Farm. According to the recommendation of Egyptian Ministry of Agriculture and Land Reclamation, fruits were planted on hills by adopting all recommended package of practices except the treatments which were conducted in five rows of $3 \mathrm{~m}$ in length with $50 \mathrm{~cm}$ between rows and a distance of $35 \mathrm{~cm}$ between plants in the rows. After five weeks, seedlings were thinned to one plant per hill. The trial was laid out using randomized complete block design with split plot arrangement and having three biofertilizers rates in the main plots, while three herbicides treatments (two herbicides used alone and sequentially), in addition to untreated control in the subplots and each treatment was replicated four times.

Table 1 Physical and chemical properties of the experimental soil

\begin{tabular}{|c|c|c|c|c|c|c|c|c|c|c|c|c|}
\hline \multicolumn{13}{|c|}{ Available (mg/kg soil) } \\
\hline $\mathrm{N}$ & & $\mathbf{P}$ & & $\mathrm{K}$ & & $\mathrm{Fe}$ & & $\mathrm{Zn}$ & & $\mathrm{Mn}$ & & $\mathrm{Cu}$ \\
\hline 29.9 & & 6.77 & & 273.00 & & 5.41 & & 3.08 & & 6.00 & & 7.74 \\
\hline \multirow[t]{2}{*}{$\mathrm{CaCO}_{3}(\%)$} & \multirow[t]{2}{*}{ O.M (\%) } & \multicolumn{4}{|c|}{ Cations (Meq/l) } & \multicolumn{4}{|c|}{ Anions (Meq/l) } & SP & $\mathrm{EC}(\mathrm{ds} / \mathrm{m})$ & $\mathrm{pH}$ \\
\hline & & $\mathrm{K}^{+}$ & $\mathrm{Na}^{+}$ & $\mathrm{Mg}^{+2}$ & $\mathrm{Ca}^{+2}$ & $\mathrm{SO}_{4}^{-2}$ & $\mathrm{Cl}$ & $\mathrm{HCO}_{3}^{-}$ & $\mathrm{CO}_{3}^{-2}$ & & & \\
\hline 0.66 & 2.2 & 1.0 & 6.6 & 2.1 & 3.3 & 2.5 & 9.4 & 1.1 & - & 60 & 1.43 & 8.02 \\
\hline
\end{tabular}




\section{Biofertilizer treatments}

The three biofertilizer rates were F1: (1:1:1), F2: (2:1:1) and F3: (1:1:2) (v/v/v) obtained from the highly efficient bacterial strains of; Azotobacter Croccuccum and Azospirillum brasilense (mixed well together by 1:1 $(\mathrm{v} / \mathrm{v})$ ) used for atmospheric nitrogen fixation, Bacillus megatherium var. phosphaticum for phosphorus-dissolving and Bacillus circulans as potassium-solubilizing bacteria, respectively. These bacterial solutions were prepared individually in the Agricultural Microbiology Department, Soils, Water and Environment Institute, A.R.C. Giza, Egypt. The strains were independently grown in nutrient broth for $48 \mathrm{~h}$ at $30^{\circ} \mathrm{C}$ in a rotary shaking incubator. The density of each bacterial culture in broth was counted using a hemocytometer. Each individual bacterium was grown and maintained on its specific medium to a density not less than $10^{8}$ cells $\mathrm{ml}^{-1}$ in the broth culture. Inoculation was performed just before sowing: Bacterial suspension was mixed with fennel fruits before planting. After planting, this mixture of bacteria was applied to the plants' rhizosphere at the root zone during furrow irrigation at 45 and 90 days after transplanting.

\section{Herbicide treatments \\ Fluazifop-p-butyl}

Fluazifop-p-butyl was used at the recommended rate (1.25 l/feddan) under the trade name Fusilade 12.5\% EC manufactured by Syngenta.

\section{Pendimethalin}

Pendimethalin was used at the half rate $(0.75 \mathrm{l} /$ feddan) under the trade name Stomp 45.5\% CS manufactured by BASF.

Herbicides application comprised five treatments of (H1) untreated check (unweeded control), (H2) untreated check (hand weeding-control), (H3) pendimethalin at reduced rate; $340 \mathrm{~g}$ a.i. feddan ${ }^{-1}$, as pre-emergence (after sowing and before irrigation), (H4) fluazifop-p butyl at the recommended rate; $190 \mathrm{~g}$ a.i. feddan ${ }^{-1}$ as postemergence (30 days after sowing) and (H5) a combination of sequential application of pendimethalin at the half rate + fluazifop butyl at the recommended rate. The rates of the herbicides were based on the recommended rate for vegetable crops as shown on the label specified by the manufacturers (since in Egypt, there are no registered herbicides for weed control in medicinal plants). Herbicides were applied once and sprayed with operated knapsack sprayer fitted with flat fan nozzle using spray volume 5001 feddan $^{-1}$. Water was applied for the untreated control in the same manner used for the other treatments.

\section{Measurements and analysis}

\section{Growth parameters and fruit yield measurements}

When the fennel fruits reached a stage of maturity, they were harvested at their full ripeness with a sickle in the early morning to avoid scattering of fruits. The collected samples were dried in a shaded and a well-ventilated area for ten days, and then, threshing was done carefully to avoid breaking theme. The plant height from the surface of the soil to the highest umbel, branches number/plant, plant fresh weigh $(\mathrm{g})$ and number of umbels/plant, were measured. Yield parameters recorded in this experiment were fruit yield/plant $(\mathrm{g})$ and fruit yield/fed $(\mathrm{kg})$.

\section{Chemical analysis \\ Fruits essential oil and its components}

To determine the essential oil (\%), the oil was extracted by hydro-distillation method in a Clevenger apparatus according to the method recommended by the Egyptian Pharmacopoeia (1984). Fennel fruits (100 g) were ground and immediately hydro-distillated for an average duration of three hours as reported by Guenther (1961). The essential oil yield was calculated as the ratio between the volume of oil obtained and the weight of fruits used. The essential oil recovered was dehydrated by anhydrous sodium sulfate and stored in a small opaque flask at $4{ }^{\circ} \mathrm{C}$ in a dark place before analysis. The volatile oil obtained from the fennel fruits was analyzed in Laboratory of Medicinal and Aromatic Plants Research Department, Horticulture Research Institute, A.R.C., by gas chromatography using Ds-Chrome 6200 Gas Chromatograph apparatus, equipped with a flame ionization detector for separation of volatile oil constituents. The analysis conditions were as follows: The chromatograph apparatus was fitted with capillary column BPX-5, 5 phenyl (equiv.) polysillphenylene-siloxane $30 \times 0.25 \mathrm{~mm}$ ID $\times 0.25 \mu$ film. Temperature program ramp increase rate of $10{ }^{\circ} \mathrm{C} / \mathrm{min}$ was from $70{ }^{\circ} \mathrm{C}$ to $200{ }^{\circ} \mathrm{C}$. Flow rates of gases were nitrogen at $1 \mathrm{ml} / \mathrm{min}$, hydrogen at $30 \mathrm{ml} / \mathrm{min}$ and $330 \mathrm{ml} / \mathrm{min}$ for air. Detector and injector temperatures were $300{ }^{\circ} \mathrm{C}$ and $250{ }^{\circ} \mathrm{C}$, respectively. The identification of the different constituents was done by comparing their retention times with those of the authentic samples.

\section{Fruit protein content}

Protein was determined as total nitrogen by micro-Kjeldahl method as described by Helrich (1990).

\section{Determination of herbicide residues}

Analytical procedures for fluazifop and pendimethalin

Herbicide residues were determined by the QuEChERS method (Anastassiades et al. 2003). For the extraction procedure, $2 \mathrm{~g}( \pm 0.1)$ of the seed sample homogenate was weighted into $50-\mathrm{ml}$ falcon centrifuge tubes. Then 
$10 \mathrm{ml}$ of distilled water and $10 \mathrm{ml}$ acetonitrile (1\% formic acid) were added, and the screw cap was closed and the tube vigorously shaken for 1 min using a vortex mixer at maximum speed. After addition of QuEChERS liquid extraction salt, containing magnesium sulfate anhydrous $(4 \mathrm{~g})$ and sodium chloride $(1 \mathrm{~g})$ for fluazifop analysis, the same extraction salt was the same in case of pendimethalin analysis, but with the addition of sodium citrate dibasic sesquihydrate $(0.5 \mathrm{~g})$ and sodium citrate tribasic dehydrate $(1 \mathrm{~g})$. The mixture was vortexed again for $1 \mathrm{~min}$ and then centrifuged for $5 \mathrm{~min}$ at $4000 \mathrm{rpm}$ at $5{ }^{\circ} \mathrm{C}$ using a refrigerated centrifuge.

\section{Determination of fluazifop}

The extract was transferred to a vial after filtered through a $0.22-\mu \mathrm{m}$ PTFE filter (Millipore, Billerica. MA) for determination by HPLC. The HPLC system was an Agilent HPLC 1260 infinity series (Agilent Technologies) equipped with a quaternary pump, a variable wavelength diode array detector (DAD), an autosample with an electric sample valve. The HPLC apparatus was equipped with an analytical column $(150 \mathrm{~mm} \times 4.6 \mathrm{~mm}$ id, $\times 5 \mu \mathrm{m}$ ODS). The flow rate of mobile phase (acetonitrile $80 \%$ + water $20 \%$ ) was $1.5 \mathrm{ml} / \mathrm{min}$, injection volume was $20 \mu \mathrm{l}$, and the detection wavelength was set at $270 \mathrm{~nm}$.

\section{Determination for pendimethalin}

Gas chromatograph HP 6890 with autosampler HP 7673 was equipped with double micro-electron capture detector $(\mu \mathrm{ECD})$ with capillary, column, $(30 \mathrm{~m} \times 0.32 \mathrm{~mm} \times 0.25 \mu \mathrm{m}) 5 \%$ phenylmethyl polysiloxane (HP5). Injector temperature was $250{ }^{\circ} \mathrm{C}$, detector temperature $300{ }^{\circ} \mathrm{C}$, flow rate of $\mathrm{N} 2(1 \mathrm{ml} / \mathrm{min})$. Temperature programs of $\mathrm{GC}$ were as follows: initial temperature $70{ }^{\circ} \mathrm{C}$ for $2 \mathrm{~min}$, rise $5{ }^{\circ} \mathrm{C} / \mathrm{min}$ up to $200{ }^{\circ} \mathrm{C}$ and held for $2 \mathrm{~min}$, then $5^{\circ} \mathrm{C} / \mathrm{min}$ up to $260^{\circ} \mathrm{C}$ and held to $5 \mathrm{~min}$.

\section{Statistical analysis}

Data obtained during the two seasons were subjected to the statistical analysis using ANOVA in split plot design according to Gomez and Gomez (1984). Means of the treatments were compared by the least significant differences (L.S.D.) at $5 \%$ level of significance as developed by Waller and Duncan (1969).

\section{Results \\ Effect of biofertilizer levels on fennel growth yield parameters and fruit chemical composition in the two seasons}

The present study clearly shows that growth, yield and fruit chemical features of fennel significantly responded to various levels of the application of biofertilizers. Data in Table 2 showed that the biofertilization with the atmospheric nitrogen fixation bacteria at F2 significantly increased fennel growth parameter, fruit production and fruit chemical composition, where the highest values of increase resulted by F2as plant height (101.23 and $103.57 \mathrm{~cm}$ ), plant fresh weight $(346.74$ and $352.79 \mathrm{~g}$ ) and number of branches/plant (43.27 and 43.27) as well as number of umbel/plant (30.29 and 36.13) in the first and second season, respectively. Moreover, values of yield parameters represented by fruit yield/plant (g) and fruit yield/fed $(\mathrm{kg})$ showed the same trend obtained above recording $43.27 \mathrm{~g}$ and $1081.9 \mathrm{~kg}$ in the first season and $48.64 \mathrm{~g}$ and $1216.1 \mathrm{~kg}$ in the second one, respectively. In addition, the highest amounts of oil \%, oil yield/plant and content of protein in fruits were obtained with F2 by $1.57 \%, 0.74 \mathrm{ml}$ and $12.88 \%$, respectively, for the first season, while $1.62 \%, 0.86 \mathrm{ml}$ and $12.92 \%$ for the second season. On the other hand, the lowest increase resulted by the high level of potassium solubilizing bacteria in F3 level is as follows: $87.68,88.90 \mathrm{~cm}$ for plant height, 207.71, $213.76 \mathrm{~g}$ for plant fresh weight, 21.39, 21.39 for number of branches/plant and 18.31, 23.88 for number of

Table 2 Fennel growth, yield parameters and fruit chemical composition affected by the biofertilizers during 2017/2018 and 2018/2019

\begin{tabular}{|c|c|c|c|c|c|c|c|c|c|c|c|c|c|c|c|c|c|c|}
\hline \multirow{3}{*}{$\begin{array}{l}\text { Biofertilizer } \\
\text { treatments* }\end{array}$} & \multicolumn{8}{|c|}{ Growth parameters } & \multicolumn{4}{|c|}{ Yield parameters } & \multicolumn{6}{|c|}{ Fruit chemical composition } \\
\hline & \multicolumn{2}{|c|}{ Plant height } & \multicolumn{2}{|c|}{$\begin{array}{l}\text { F.W of plant } \\
\text { (g) }\end{array}$} & \multicolumn{2}{|c|}{$\begin{array}{l}\text { No. of } \\
\text { branches/ } \\
\text { plant }\end{array}$} & \multicolumn{2}{|c|}{$\begin{array}{l}\text { Umbels/ } \\
\text { plant }\end{array}$} & \multicolumn{2}{|c|}{$\begin{array}{l}\text { Fruit yield/ } \\
\text { plant (g) }\end{array}$} & \multicolumn{2}{|c|}{$\begin{array}{l}\text { Fruit yield } \\
(\mathrm{kg}) / \mathrm{fed}\end{array}$} & \multicolumn{2}{|c|}{ Oil\% } & \multicolumn{2}{|c|}{$\begin{array}{l}\text { Oil Yield } \\
\text { (ml)/ } \\
\text { plant }\end{array}$} & \multicolumn{2}{|c|}{$\begin{array}{l}\text { Fruit Protein } \\
\text { content (\%) }\end{array}$} \\
\hline & $1 \mathrm{st}$ & 2nd & $1 \mathrm{st}$ & 2nd & $1 \mathrm{st}$ & 2nd & $1 \mathrm{st}$ & 2nd & $1 \mathrm{st}$ & 2nd & $1 \mathrm{st}$ & 2nd & $1 \mathrm{st}$ & 2nd & $1 \mathrm{st}$ & 2nd & 1st & 2nd \\
\hline F1 & 99.79 & 100.38 & 275.11 & 281.70 & 34.48 & 34.48 & 24.13 & 29.78 & 34.48 & 39.73 & 861.9 & 993.2 & 1.40 & 1.41 & 0.56 & 0.64 & 12.06 & 12.13 \\
\hline $\mathrm{F} 2$ & 101.23 & 103.57 & 346.74 & 352.79 & 43.27 & 43.27 & 30.29 & 36.13 & 43.27 & 48.64 & 1081.9 & 1216.1 & 1.57 & 1.62 & 0.74 & 0.86 & 12.88 & 12.92 \\
\hline F3 & 87.68 & 88.9 & 207.71 & 213.76 & 21.39 & 21.39 & 18.31 & 23.88 & 21.39 & 26.89 & 534.8 & 672.2 & 1.27 & 1.28 & 0.32 & 0.40 & 10.40 & 10.47 \\
\hline LSD at $5 \%$ & 7.37 & 3.21 & 9.16 & 7.52 & 0.93 & 0.93 & 2.19 & 2.20 & 0.93 & 1.08 & 23.32 & 27.20 & 0.07 & 0.07 & 0.02 & 0.04 & 0.20 & 0.18 \\
\hline
\end{tabular}

${ }^{*}$ The three biofertilizer rates F1: 1:1:1, F2: 2:1:1 and F3: 1:1:2 (v/v/v) from the highly efficient bacterial strains of atmospheric nitrogen fixation, phosphorous dissolving and potassium solubilizing, respectively 


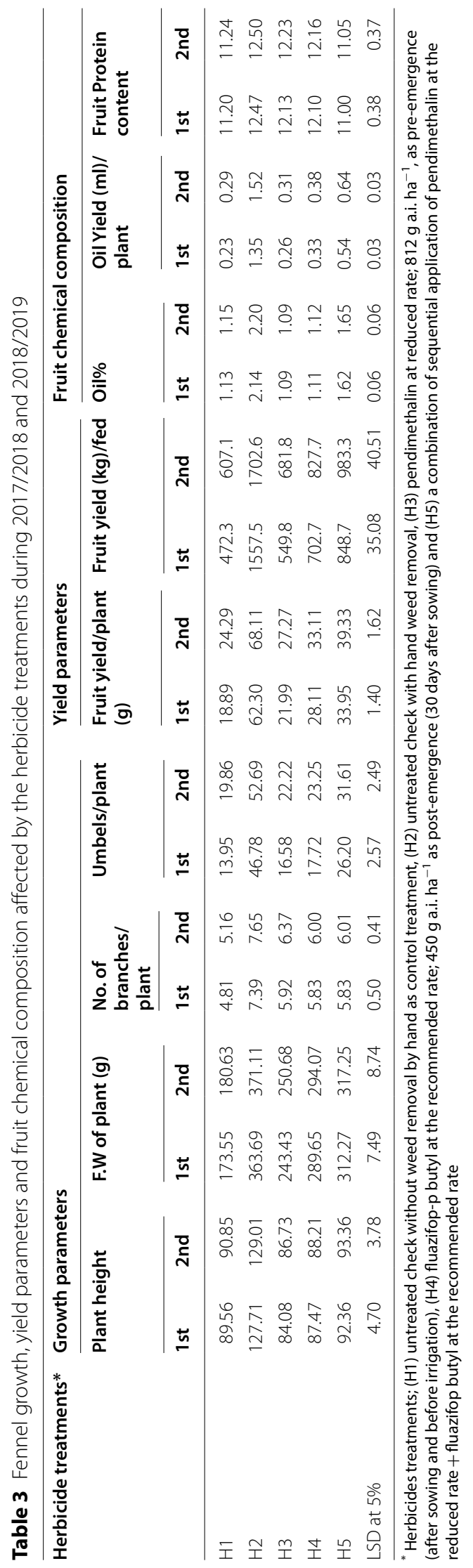


umbels/plant in the first and second season, respectively, whereas at the F3 (the high level of potassium solubilizing bacteria), elevated levels of fruit yield/plant (g), fruit yield/fed $(\mathrm{kg})$, oil \%, oil yield/plant and protein content in fruits compared with untreated were (21.39 and $26.89 \mathrm{~g})$, (534.8 and $672.2 \mathrm{~kg}),(1.27$ and $1.28 \%),(0.32$ and $0.40 \mathrm{ml})$ and (10.40 and $10.47 \%)$ in both seasons, respectively.

\section{Effect of herbicide treatments on fennel growth, yield parameters and fruit chemical composition in the two seasons}

The data for the growth and yield parameters of fennel can be seen in Table 3. It is noticed that there were significant differences among herbicide treatments in the growth and yield parameters as well as fruit chemical composition. Generally, the herbicides negatively affected the studied parameters of fennel compared to hand weeding check (H2). Data showed that the highest increase in the growth, yield parameters and oil \% as well as oil yield per plant were obtained with the treatment of $\mathrm{H} 2$ followed by $\mathrm{H} 5$ then $\mathrm{H} 4$ and $\mathrm{H} 3$, while the lowest value was observed with the treatment of $\mathrm{H} 1$. It is that the fennel yield was affected by spraying pendimethalin followed by fluazifop (H5) as the yield measured was 45.50 and $42.25 \%$ lower compared with hand weed removal $(\mathrm{H} 2)$. On the contrary, compared to the control (untreated check), the combination of pendimethalin + fluazifop (H5) contributed to an increase in fennel yield by 44.35 and $38.26 \%$ in the two seasons. On the other hand, the use of pendimethalin at reduced rate $(\mathrm{H} 3)$ exhibited increase in the yield by 14.09 and $10.96 \%$, while fluazifop-(H4) recorded 32.78 and $26.65 \%$ higher yield than that in the control H1 (unweeded check). Concerning the fruit protein content, data in Table 3 revealed that the maximum values were obtained with the treatment of $\mathrm{H} 2$ (12.47 and $12.50 \%)$ then $\mathrm{H} 3$ (12.13 and $12.23 \%)$ followed by H1 (11.20 and 11.24\%). However, the minimum values were observed with $\mathrm{H} 5$ treatment $(11.00,11.05 \%)$ in both seasons. The treatment of $\mathrm{H} 5$ had a positive effect on plant height (92.36 and 93.36) than H3 (84.08 and 86.73) or H4 (87.47 and 88.21), compared to H1 (89.56 and 90.85) in both seasons. The essential oil content in fennel fruits and the essential oil yield is given in Table 3 . The herbicide sequential application of pendimethalin and fluazifop butyl (H5) decreased the oil content in fruits compared to H2 (untreated check-hand weeded). In addition, when the two herbicides applied alone, each of them also reduced the oil content in fruits compared to H2. Nonetheless, the oil yield increased compared with $\mathrm{H} 1$ (the untreated and unweeded check). The lowest oil yield was obtained from H3 (80.17\%) which was less than that the hand weeded control (H2) in both seasons, while the highest increase (56\%) in the yield was recorded in case of the sequential combination of pendimethalin and fluazifop, compared with the unweeded control (H1).

\section{The interactive effect of the herbicide treatments under biofertilizer rates on fennel growth yield parameters and fruit chemical composition in the two seasons}

Data in Table 4 indicated that significant influence of plant and fruiting characteristics, volatile oil percentage, oil yield and fruit protein content of fennel plants were obtained. The application of F2 with $\mathrm{H} 2$ resulted in the highest values in plant height (134.86 and $137.05 \mathrm{~cm})$, fresh weight per plant (416.9 and $425.31 \mathrm{~g}$ ), number of branches (8.0 and 8.5), number of umbels/plant (57.31, $63.39)$, fruit yield per plant $(71.18,78.01 \mathrm{~g})$ and per feddan $(1779.5,1950.3 \mathrm{~kg})$, volatile oil $(2.41,2.55 \%)$, oil yield per plant $(1.71,1.98 \mathrm{ml})$ and fruit protein $(13.56,13.56 . \%)$ in both seasons. Additionally, application of H5x F2 led to a slight decrease in values for all measured parameters as compared to the $\mathrm{F} 2 \mathrm{xH} 2$. The average of reduction \% in both seasons was $(28.58,6.63,17.78,32.31,32.77,32.77$, 41.52, 60.42 and 4.50) for plant height, fresh weight/ plant, number of branches, number of umbels/plant, fruit yield/plant and feddan, volatile oil and oil yield per plant and the fruit protein, respectively. On the other hand, the increment \% in both seasons for H5x F2 compared to $\mathrm{H} 1 \mathrm{xF} 2$ was $1.77,56.27,35.20,118.83,77.06,77.06$ and $76.67 \%$ for plant height, fresh weight/plant, number of branches, number of umbels/plant, fruit yield/plant and feddan, oil yield per plant, respectively, whereas oil \% and protein content showed decrease by 21.33 and $2.85 \%$, respectively. Similarly, $\mathrm{H} 4 \mathrm{xH} 2$ treatments showed higher amount of protein content than $\mathrm{H} 5 \mathrm{xH} 2$, while no significant of difference compared to $\mathrm{F} 2 \mathrm{xH} 2$ was determined.

\section{GLC analysis of essential oil composition}

The essential oil of the produced fennel seeds in all treatments was subjected to fractionation using gas chromatography (GC). From the data presented in Table 5, limonen, 1,8 cineol and methyl chavicol were recorded as the main components. The concentration of the major component methyl chavicol (estragole) ranged from $75.60 \%$ to $81.85 \%$ followed by limonen $(8.43-20.80 \%)$; then, 1,8 cineol ranged $(2.07-6.69 \%)$ in all the treatments. The minor compounds were $\alpha$-pinene, myrcene and anethole. The most noticeable treatment that decreased the concentration of methyl chavicol (65.14\%), resulted from biofertilizer (F3) and both herbicides combination (fluazifop + pendimethalin) treatment followed by the treatment of biofertilizer (F2) and untreated check (hand weeded) that recorded $67.39 \%$. On the contrary, plants treated with biofertilizer (F2) and sprayed with both herbicides combination (fluazifop + pendimethalin) exhibited the highest content of methyl chavicol (81.85\%). 


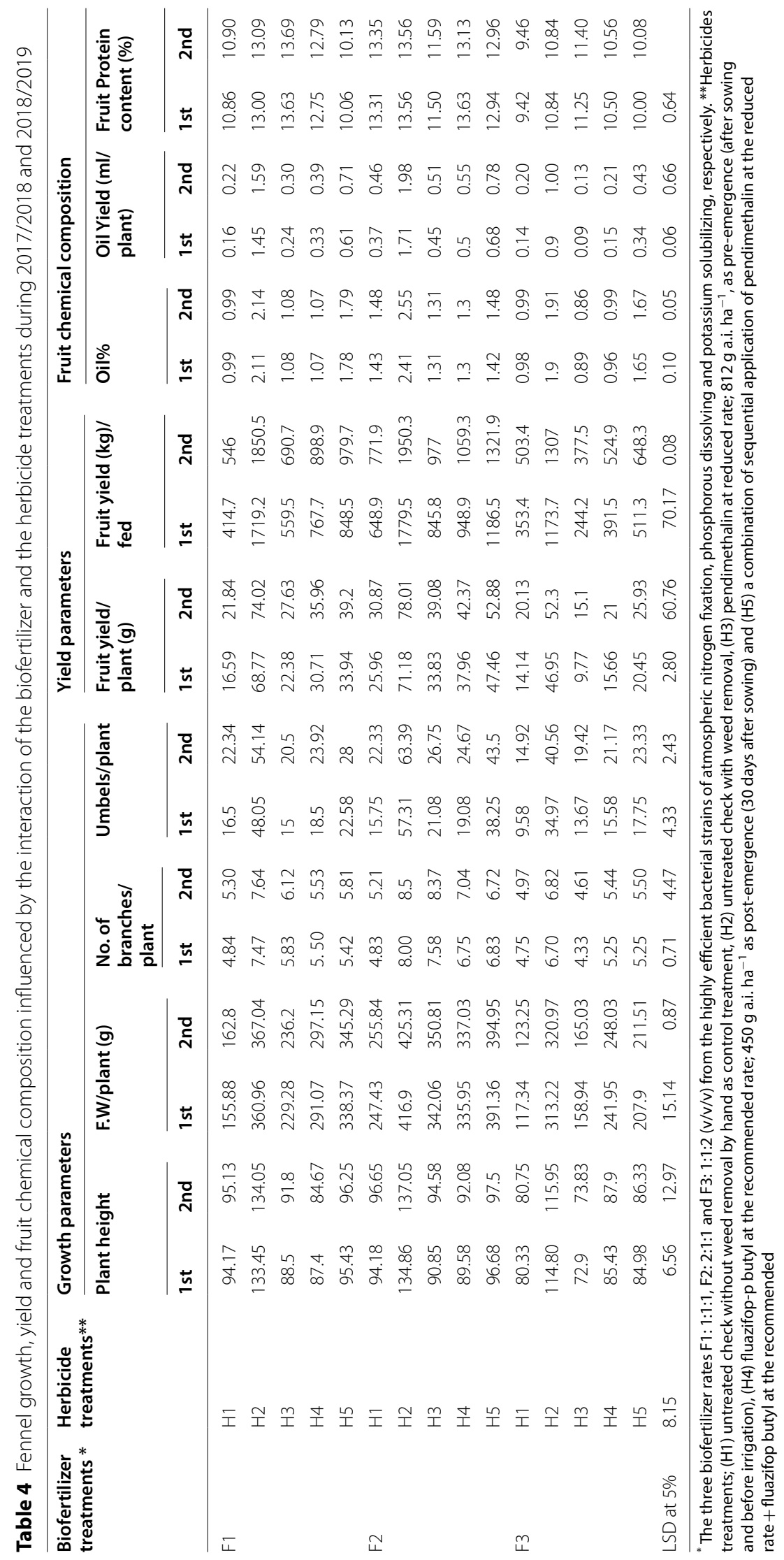


Table 5 Effect of biofertilizer and herbicides on fennel oil composition

\begin{tabular}{|c|c|c|c|c|c|c|c|}
\hline \multirow{2}{*}{$\begin{array}{l}\text { Rates of } \\
\text { biofertilizer* } \\
\text { (v:v:v) }\end{array}$} & \multirow{2}{*}{$\begin{array}{l}\text { Herbicide } \\
\text { treatments }\end{array}$} & \multicolumn{6}{|c|}{ Major essential oil constituents (\%) } \\
\hline & & a-pinene & Myrcene & Limonene & 1,8 Cineole & Methyl chavicol & Anethole \\
\hline \multirow[t]{5}{*}{$\mathrm{F} 1$} & $\mathrm{H} 1$ & 0.11 & 1.31 & 14.59 & 4.62 & 77.59 & 0.44 \\
\hline & $\mathrm{H} 2$ & 1.43 & 0.92 & 15.93 & 4.55 & 76.15 & 0.64 \\
\hline & $\mathrm{H} 3$ & 0.71 & 0.83 & 13.34 & 2.62 & 79.97 & 1.33 \\
\hline & $\mathrm{H} 4$ & 0.95 & 0.96 & 16.46 & 6.53 & 72.54 & 0.70 \\
\hline & $\mathrm{H} 5$ & 2.05 & 1.11 & 15.38 & 6.77 & 69.79 & 1.71 \\
\hline \multirow[t]{5}{*}{ F2 } & $\mathrm{H} 1$ & 0.96 & 0.98 & 16.59 & 6.36 & 72.29 & 0.70 \\
\hline & $\mathrm{H} 2$ & 2.02 & 1.21 & 15.14 & 6.69 & 67.39 & 2.16 \\
\hline & $\mathrm{H} 3$ & 1.45 & 1.15 & 16.87 & 2.64 & 75.60 & 0.29 \\
\hline & $\mathrm{H} 4$ & 1.43 & 0.29 & 17.42 & 2.72 & 76.58 & 0.39 \\
\hline & $\mathrm{H} 5$ & 1.41 & 1.05 & 9.32 & 4.5 & 81.85 & 0.59 \\
\hline \multirow[t]{5}{*}{ F3 } & $\mathrm{H} 1$ & 1.98 & 0.74 & 14.15 & 2.42 & 78.86 & 0.24 \\
\hline & $\mathrm{H} 2$ & 1.20 & 0.88 & 12.61 & 2.72 & 81.58 & 0.31 \\
\hline & $\mathrm{H} 3$ & $2 . .22$ & 0.79 & 8.43 & 4.86 & 78.37 & 0.33 \\
\hline & $\mathrm{H} 4$ & 1.15 & 0.99 & 20.80 & 2.07 & 74.48 & 0.50 \\
\hline & $\mathrm{H} 5$ & 2.07 & 0.85 & 15.50 & 6.68 & 65.14 & 1.93 \\
\hline
\end{tabular}

${ }^{*}$ The three biofertilizer rates F1: 1:1:1, F2: 2:1:1 and F3: 1:1:2 (v/v/v) from the highly efficient bacterial strains of; atmospheric nitrogen fixation, phosphor dissolving and potassium solubilizing, respectively. ${ }^{* *}$ Herbicides treatments; $(\mathrm{H} 1)$ untreated check without weed removal by hand as control treatment, $(\mathrm{H} 2)$ untreated check with weed removal, $(\mathrm{H} 3)$ pendimethalin at reduced rate; $812 \mathrm{~g}$ a.i. ha ${ }^{-1}$, as pre-emergence (after sowing and before irrigation), (H4) fluazifop-p butyl at the recommended rate; $450 \mathrm{~g}$ a.i. ha ${ }^{-1}$ as post-emergence (30 days after sowing) and ( $\left.\mathrm{H} 5\right)$ a combination of sequential application of pendimthalin at the half rate + fluazifop butyl at the recommended rate

Table 6 Recovery percentages of fluazifop and pendimethalin

\begin{tabular}{lllll}
\hline Herbicide & $\begin{array}{l}\text { Fortification } \\
\text { levels }(\boldsymbol{\mu g} / \mathbf{g}) \\
\boldsymbol{n}=\mathbf{5}\end{array}$ & \% Mean recovery & LOQ & $\begin{array}{l}\text { RSD } \\
\%\end{array}$ \\
\hline Fluazifop-p-butyl & $0.03-0.3$ & 82.3 & 0.03 & 4.16 \\
Pendimethalin & $0.05-0.5$ & 91.6 & 0.05 & 1.99 \\
\hline
\end{tabular}

$n=$ number of replicates

$\mathrm{RSD}=$ relative standard deviation

\section{Determination of herbicide residues in fennel fruit seeds}

Data in Table 6 showed that the average recovery percent was 82.3 for fluazifop and 91.6 for pendimethalin. Values of the recovery and RSD \% were within the acceptable limits for routine analysis of herbicide residues. LOQ was 0.03 and $0.05 \mathrm{mg} \mathrm{kg}^{-1}$, for fluazifop and pendimethalin, respectively, indicating good analytical precision. A calibration curve was plotted of concentration of the fluazifop and pendimethalin standards injected versus area observed. The peak areas obtained from different concentrations of standards were used to calculate linear regression equation with correlation coefficient of 0.99 showing better analytical sensitivity and accuracy. A calibration curve is shown in Figs. 1 and 2. No detectable residues of fluazifop and pendimethalin applied alone or sequentially were found in the analyzed dry seeds.
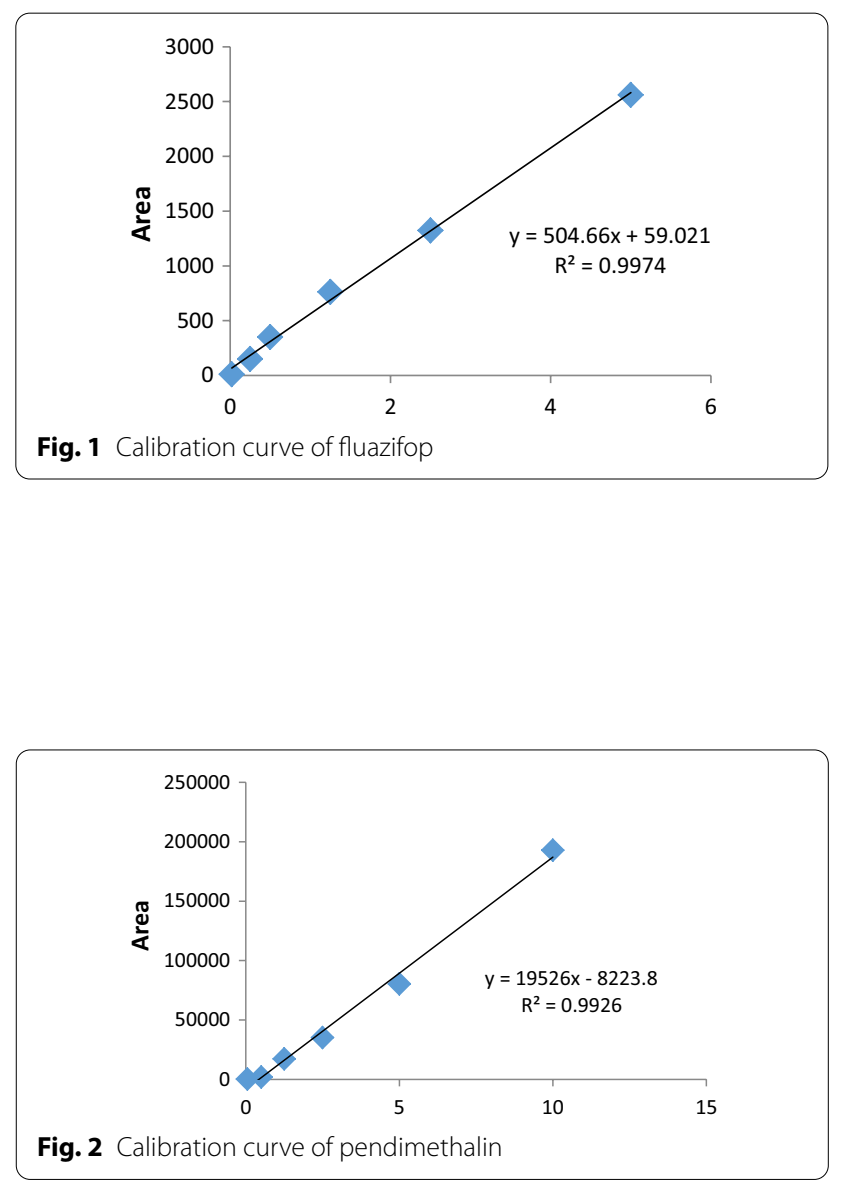


\section{Discussion}

\section{Effect of biofertilizers}

The ongoing global research to exploit biofertilization as an alternative to chemical fertilization in medicinal and aromatic plants has been reported by many scholars (Darzi et al. 2012; Talaei et al. 2014; El Naggar 2017; El-Serafy 2018; Rahimi et al. 2019; El-Serafya and ElSheshtawy 2020). In the current study, the stimulating effect of $\mathrm{N}$ fixing bacteria (F2: 2:1:1) on fennel growth and fruit yield may be attributed to that the biofertilizer can directly enhance plant growth through increasing atmospheric nitrogen fixation, minerals solubilization, siderophores production that solubilize and sequester iron, or realizing the plant growth regulators or due to phytohormones released by $\mathrm{N}$-fixers such as IAA (Taghavi et al. 2009) and GAs. These phytohormones enhance cell elongation, cell division and differentiation in plants (Cleland 1990; Hagen 1990). Umbels number per plant and fruit yield showed significant increase with biofertilization which could be attributed to nitrogen-fixing bacteria that can fix about $20-200 \mathrm{~kg} \mathrm{~N}^{-1}$ and promote plant growth and productivity by $10-50 \%$ (Bashan 1998). Also, it can indirectly affect plant growth by inducing of IBA and tryptophol (Lebuhn et al. 1997; El-Khawas and Adachi 1999) or ameliorating growth restricting conditions either via production of antagonistic substances or induction of plant pathogens resistance (Kloepper 1994). Moreover, results indicated that fennel oil content was improved with the treatment that was rich in nitrogen-fixing bacteria inoculation (F2). The improvement in fruit yield and oil content affected by nitrogen-fixing bacteria inoculation (F2) has been previously reported (Mahfouz and Sharaf Eldin 2007; Ghazal and Shahhat 2012). Application of nitrogen-fixing bacteria showed a reduction in estragole content and an increase in anethole content in fennel oil. Nitrogen fixers supply plant requirements of nitrogen by slow releasing during plant cycle (Sefidkon 2012). Nitrogen is so vital element for building chlorophyll, amino acids, proteins, nucleic acids, enzymes and energy-transfer compounds such as phenylalanine (the main amino acid for estragole "methyl chavicol" synthesis), hexokinase, enolase, chorismate synthase, O-methyl transferase, phenylalanine ammonia-lyase "PAL" and $S$-adenosylmethionine "SAM" enzymes and the co-enzymes ATP and NADPH which are involved in estragole synthesis (Yoshida 1969). The reduction in estragole content with biofertilization in relation to chemical fertilization has been reported in two fennel varieties: vulgare and azoricum (Ghazal and Shahhat 2012), anise (Hassan and Ali 2013) and basil (Sakr et al. 2014; Mohamed et al. 2016). Several studies have reported the positive effect of nitrogen-fixing bacteria inoculation on essential oil crops; Gad (2001) on fennel and dill; Badran and Safwat (2004) on fennel; Darzi et al. (2012) on coriander; Talaei et al. (2014) on fennel and other crops; Saxena et al. (2013) and Talaat (2019) on bean.

\section{Effect of herbicides}

It is known that most of the medicinal plants are less competitive than weeds and suffer from heavy infestation of several annual weeds particularly during the early life stage due to fennel's slow growth, a prolonged flowering period and low harvest index (Hendawy et al. 2020). Weeds can cause $28.5 \%$ reduction in growth and yield of fennel (Hendawy et al. 2020). Nevertheless, weed management in medicinal plants (fennel) seems to be more complicated compared to other crops. Limited information regarding effects of herbicides (as the most superior and effective weed control method), on growth and development of medicinal plants is available. Chemical treatments have been studied with contrasting results, but an interference of herbicides with the metabolism of secondary products was found in some cases (Carrubba 2017). Our results showed that postemergence herbicide, fluazifop reduced plant development after application. We observed (visually) that fennel seedlings were more sensitive to pendimethalin that fluazifop. The adverse effects of the pendimethalin (H3) on the growth of fennel plant were detected in the measured parameters. These results are reinforced with those achieved by Meena and Mehta (2009) on fennel. Similar observations on garlic were reported by Adam et al. (1996). The growth inhibition caused by the herbicide was, however, reflected on the productivity as yield component characteristics were markedly declined. Likewise, Kothari et al. (2002) and Meena and Mehta (2009) had reported that pendimethalin reduced yield components of fennel. In this respect, this reduction in fennel yield may be attributed to the disturbance effects on the photosynthetic process due to the suppression of the biosynthesis of the photosynthetic pigments and inhibiting respiration as well (Shabana et al. 1991; El-Awadi and Hassan 2011). Janmohammadi et al. (2017) also pointed out that trifluralin (chemically and actively similar herbicide to pendimethalin) had adverse effect on the growth and flowering of the aromatic plant, dragonhead (Dracocephalum moldavica). However, Starratt and Lazarovits (1999) recorded an increase in the free amino acids in melon seedlings in response to exposure to dinitroaniline herbicides (e.g., pendimethalin). In the present results, different observations were noted on the fennel plant, where a significant reduction observed in total protein content. In this connection, another dinitroaniline herbicide, butralin caused remarkable reduction in protein, carbohydrate, leghaemoglobin and ureide in the nodule fraction of soybean (Mahmoud et al. 1996). 
Yousefi and Rahimi (2014) and Zheljazkov (1998) stated that the preemergence application of linuron, trifluralin and pendimethalin did not inhibit germination and did not cause phytotoxic damage to fennel. In contrast, they stated that pendimethalin at reduced recommended rate produced consistently high fennel yields. In our results, it was observed a reduction in growth characters after application of fluazifop treatment alone (H4). In addition, the combination of the two herbicides showed the best values in all studied characteristics compared to the application of each one individually. Several researchers indicated that the herbicide combinations are more effective for weed control than individual herbicide applications. Application of herbicides may have a positive effect on growth and crop seed yield and its components (Soliman et al. 2015). They found that pendimethalin/fluazifop-p-butyl combined treatment increased oil content/ seeds in soybean, but not the protein. Singh et al. (2017) showed also that application of pre-mix pendimethalin + postemergence herbicides gave higher green gram grain yields due to significant reduction in the dry weight of weeds and higher weed control efficiency and consequently improving the yield attributing parameters. Additionally, herbicide treatments including both pendimethalin and fluazifop recorded significantly higher nutrient uptake in groundnut as compared to unweeded control which helped the crop to grow in weed free environment and absorb more nutrients from the soil. This has resulted in increased dry matter production and growth per plant (Basavaraj et al. 2014). The use of herbicides for weed control in medicinal plants led to a $90 \%$ reduction of the weed, and a $65 \%$ reduction of the manual work was needed for weed control (Pank et al. 1980; Hendawy et al. 2020). Similarly, Kumar and Tewari (2004) found that pendimethalin (1.0 and $\left.1.25 \mathrm{~kg} \mathrm{ha}^{-1}\right)$ as pre-emergence herbicide for grass and broadleaf weeds followed by fluazifop-p-butyl $\left(0.250-0.375 \mathrm{~kg} \mathrm{ha}^{-1}\right)$ as selective post-emergence grass herbicide, enhanced weed control spectrum resulting in increased black gram grain yield over sole application of each one due to lowered weeds' density and dry weight. Same trends were obtained by Wilfred et al. (2020) as they reported that pendimethalin + haloxyfop-P-methyl (chemically related and biologically similar to fluazifop) resulted in the best growth characteristics, yield components and yield of groundnut as an oilseed crop in Guinea Savannah. Hassanein et al. (2002) pointed out that the application of pre + post-emergence herbicide in soybean significantly increased plant height, number of leaves, dry weight of leaves and total dry weight of plant and gave the highest weight of pods/plant, 100-seed weight and seed yield/ fed, compared with the unweeded treatment. On the other hand, slight phytotoxicity on fennel through all its growth stages was exhibited after application of herbicides either alone or in sequentially. Pickett and Zheljazkov (2017) pointed out that fluazifop showed potential for postemergence application with no phytotoxic damage allowing use in fennel production. Regarding herbicide residues dry seeds, it is unlikely to present a risk to consumer health. Our findings disagree with the previous study of Pickett and Zheljazkov (2017) on screening of preemergence and postemergence herbicides for weed control in dill (Anethum graveolens), fennel (Foeniculum vulgare), coriander (Coriandrum sativum) and basil (Ocimum basilicum). They noted that of the herbicides tested and based on the ratings for phytotoxic effects, ethofumesate, fluazifop-p-butyl, propyzamide and sethoxydim showed potential for use in fennel production.

\section{Interaction of biofertilizers and herbicides}

Few reports in relation with herbicides interaction with biofertilizers in Egypt are presented. Herbicides are used in broad level in agriculture, but there is no enough available research on the interaction effect of microbial fertilizers and herbicides. Herbicides not only have adverse effect on plant growth, but also may have influence on the interaction between symbiotic bacteria like rhizobium and plant growth-promoting bacteria (Brock 1975). The reduction percent in fennel yield was observed with the application of herbicide under the treatment of F2 which is rich in $\mathrm{N}_{2}$ fixing bacterial strains (Azotobacter Croccuccum and Azospirillum brasilense) compared to F1 or F3 which have less amount of $\mathrm{N}_{2}$ fixing bacteria. This may be due to that herbicides can translate to everlasting changes in the soil microflora (Aleem et al. 2003), producing adverse effect on soil fertility and crop productivity, inhibiting nitrogen $\left(\mathrm{N}_{2}\right)$-fixing bacteria (Sachin 2009) and interfering with ammonification (Reinhardt et al. 2008). This would ultimately lead to less available nitrogen required for fennel growth.

\section{Herbicide residues in fennel seeds.}

The presence of herbicides may alter the quality traits of crop essential oil conferring it an unwanted off-flavor (Rajeswara Rao et al. 2007). That would negatively affect the market end value of the herbal product and affect human health (Upadhyay et al. 2011). The application of pendimethalin and trifluralin resulted in below detectable limit residues $(0.02 \mathrm{mg} / \mathrm{kg}$ ) in celery seeds (Kaur and Gill 2012). No herbicide residues with ethalfluralin (belongs to pendimethalin group) were found in harvested thyme (Michaud et al. 1993). Jazwa et al. (2009) also pointed out that the residues of pendimethalin in ripe seeds did not exceed the average level of $0.005 \mathrm{mg} /$ $\mathrm{kg}$. Our results in harmony with those above obtained as there were no detectable levels of both herbicides in dry 
seeds. This may be attributed to the long period of crop growth of fennel. Consequently, pendimethalin got sufficient time to degrade in the soil and plants following its application; this reduced bioavailability of pendimethalin in the fennel seeds, led to that no residues at the harvest time were determined. Additionally only half the recommended rate was applied in our study, not the full rate. Regarding fluazifop-p-butyl, it is rapidly and completely metabolized within the plant to fluazifop acid two to four weeks following application (Balinova and Lalova 1992; Kulshrestha et al. 1995; Sondhia 2014). The acid form takes longer to degrade, with residues remaining in the plant up to 45 days after treatment (Balinova and Lalova 1992).

\section{Conclusion}

This study showed that regular hand weeding could be assigned as the best weed control measure since the higher yield and essential oil volume were harvested from plant grown under manual control. It also revealed that growth characters and seed yield were significantly influenced by different levels of biofertilizers and herbicides. The treatment of biofertilizer at 2:1:1 $(\mathrm{v} / \mathrm{v} / \mathrm{v})$ from the highly efficient bacterial strains of: atmospheric nitrogen fixation, phosphorous dissolving and potassium solubilizing, respectively, combined with pendimethalin + fluazifop butyl presented the second best results after the hand weeded check. Although herbicides are effective tools for controlling weeds and can reduce time and costs associated with physical/manual weed removal, their application may affect the constituents of the oils in medicinal plant and should be applied with caution. Our results concluded that using proper level of biofertilizer in reference to increase the $\mathrm{N}_{2}$ fixing bacteria combined with herbicide would increase the yield of fennel. However, further research is needed on other techniques and methods of integrated management options to achieve safer, economic and effective weed control in medicinal plants.

\section{Abbreviations}

F1: Biofertilizer at ratio of 1:1:1; F2: Biofertilizer at ratio of 2:1:1; F3: Biofertilizer at ratio of 1:2:1; $\mathrm{H1}$ : Untreated check control; $\mathrm{H2}$ : Untreated checks with hand weeding; H3: Pendimethalin; H4: Fluazifop-p butyl; H5: Pendimethalin + fluazifop butyl.

\section{Acknowledgements}

The authors are thankful for workers helped in field labor.

\section{Authors' contributions}

The first and the second authors suggested the research idea, designed the experiments, collected field data and equally contributed to interpreting results, writing and revising the manuscript. The third author performed the chromatographic analysis. All authors approved the final manuscript to be published.
Funding

The study was funded by the authors.

Availability of data and material

All data and materials are available.

\section{Declarations}

Ethics approval and consent to participate

Not applicable.

\section{Consent for publication}

Not applicable.

\section{Competing interests}

No competing of interest.

\section{Author details}

${ }^{1}$ Pesticides Department, Faculty of Agriculture, Cairo University, Giza, Egypt. ${ }^{2}$ Medicinal and Aromatic Plants Department, Horticulture Research Institute, Agricultural Research Center, Giza, Egypt. ${ }^{3}$ Central Agricultural Pesticides Laboratory, Agricultural Research Center, Giza, Egypt.

Received: 27 January 2021 Accepted: 4 April 2021

Published online: 21 April 2021

\section{References}

Abdel-Rahman SSA, Abdel-Kader AAS (2020) Response of fennel (Foeniculum vulgare, Mill) plants to foliar application of moringa leaf extract and benzyladenine (BA). S Afr J Bot 129:113-122

Adam SM, Mohamed TR, Abdalla AM (1996) Influence of some herbicides on the germination and early growth of garlic (Allium satium). Egypt J Hort 23(1):25-33

Aleem A, Isar J, Malik A (2003) Impact of long term application of industrial wastewater on the emergence of resistance traits of Azotobacter vinelandii isolated from rhizosphere soil. Biores Tech 86:7-13

Anastassiades M, Maštovská K, Lehotay SJ (2003) Evaluation of analyte protectants to improve gas chromatographic analysis of pesticides. J Chromatogr A 1015:163-184. https://doi.org/10.1016/S0021-9673(03)01208-1

Badran FS, Safwat MS (2004) Response of fennel plants to organic manure and bio-fertilizers in replacement of chemical fertilization. Egypt J Agric Res $82: 247-256$

Balinova AM, Lalova MP (1992) Translocation, metabolism and residues of fluazifop-butyl in soybean plants. Weed Res 32:143-147

Bashan Y (1998) Inoculants of plant growth-promoting bacteria for use in agriculture. Biotechnol Adv 16(4):729-770

Bird WG, Maredia MK, Dakouo D, Mota-Sanchez D (2003) Role of integrated pest management and sustainable development. In: Integrated pest management in the global arena. CABI, Wallingford, pp 73-85

Brock L (1975) Effects of the herbicides trifluralin and carbetamide on nodulation and growth of legume seedlings. Weed Res 12:145-150. https://doi. org/10.1111/j.1365-3180.1972.tb01199.x

Carrubba A (2017) Weed and weeding effects on medicinal berbs. In: Ghorbanpour M, Varma A (eds) Medicinal plants and environmental challenges. Springer, Cham. https://doi.org/10.1007/978-3-319-68717-9_17

Cleland RE (1990) Auxin and cell elongation. In: Davies PJ (ed) Plant hormones and their role in plant growth and development. Kluwer Academic, Dordrecht, pp 132-151

Darzi MT, Hadi MH, Rejali F (2012) The effects of application of manure and biological on biomass yield, grain yield and essential oil yield of medicinal plant of coriander (Coriandrum sativum). J Med Plants 9:77-90

Donald LS (1996) Methods of soil analysis part 3-Chemical methods, SSSA Book Series 5.3. Soil Science Society of America, American Society of Agronomy

Egyptian Pharmacopoeia (1984) General organization for governmental printing office, Cairo, Egypt 
Ehsanipour A, Razmjoo J, Zeinalib H (2012) Effect of nitrogen rates on yield and quality of fennel (Foeniculum vulgare Mill.) accessions. Ind Crop Prod 35:121-125

El Naggar SH (2017) Effect of fertilization and plant density on Holland fennel under Sinai condition. M.Sc. Thesis. Faculty of Agriculture-Tanta University, Egypt

El-Awadi ME, Hassan A (2011) Improving growth and productivity of fennel plant exposed to pendimethalin herbicide: stress-recovery treatments. Nat Sci 9(2):97-108

El-Ghadban EAE, Shalan MN, Abdel-Latif TAT (2006) Influence of biofertilizers on growth, volatile oil yield and constituents of fennel (Foeniculum vulgare Mill.). Egypt J Agric Res 84(3):977-992

El-Khawas H, Adachi K (1999) Identification and quantification of auxins in culture media of Azospirillum and Klebsiella and their effect on rice roots. Biol Fertil Soils 28:377-381

El-Serafy RS, El-Sheshtawy AA (2020) Effect of nitrogen fixing bacteria and moringa leaf extract on fruit yield, estragole content and total phenols of organic fennel. Sci Hortic. https://doi.org/10.1016/j.scienta.2020.109209

El-Serafy RS (2018) Growth and productivity of roselle (Hibiscus sabdariffa L.) as affected by yeast and humic acid. Sci J Flowers Ornam Plants 5(2):195203. https://doi.org/10.21608/sjfop.2018.18129

Gad WM (2001) Physiological studies on Foeniculum vulgare Mill. and Anethum graveolens L. M.Sc. Thesis. Faculty of Agriculture-Tanta University, Egypt

Ghazal GMEM, Shahhat IMAM (2012) Physiological and phytochemical responses of Foeniculum vulgare var. vulgare Mill. and Foeniculum vulgare var. azoricum Mill. to bio-organic manure as partial or full substitute for inorganic amendment. Aust J Basic Appl Sci 6(10):266-277

Gomez KA, Gomez AA (1984) Statistical procedures for agricultural research, 2nd edn. Wiley, New York, NY, p 680

Gori L, Gallo E, Mascherini V, Mugelli A, Vannacci A, Firenzuoli F (2012) Review Article: Can estragole in fennel seed decoctions really be considered a danger for human health? A Fennel safety update. Evid-Based Compl Alt. https://doi.org/10.1155/2012/860542

Guenther E (1961) The essential oils, vol III, 4th edn. D. Van Nostrand Co, New York

Hagen G (1990) The control of gene expression by auxin. In: Davies PJ (ed) Plant hormones and their role in plant growth and development. Kluwer, Dordrecht, pp 149-163

Haggag LF, Merwad MA, Shahin MFM, Fouad AA (2014) Effect of NPK and bio-fertilizers as soil application on promoting growth of "Toffahi" olive seedlings under greenhouse condition. IJAT 10(6):1593-1603

Hassan FAS, Ali EF (2013) A comparative study between traditional mineral nutrition and other alternative sources on anise plant. Eur J Sci Res 106(2):201-212

Hassanein EE, Fayed MH, Dawla NF, El Sehly SE (2002) Effect of some weed control treatments on soybean and associated weeds. Egypt J Agric Res 78(5):1979-1997

Helrich K (1990) Official methods of analysis, 15th edn. Association of Official Analytical Chemist, Washington, DC

Hendawy S, Abouziena H, El-RazikT, Amer H (2020) Winter weeds and its control in the medicinal plants in Egypt: a survey study. Egypt Pharm J. https://doi.org/10.4103/epj.epj_13_18

Ibrahim ME, Abd Rabbu HS, Motawe HM, Hussein MS (2020) Improved growth, yield of seeds and oil production of fennel (Foeniculum vulgare var. vulgare) plants. J Mater Environ Sci 11(7):1112-1120

Janmohammadi M, Nouraein M, Sabaghnia N (2017) Influence of different weed management techniques on the growth and essential oils of dragonhead (Dracocephalum moldavica L.) Rom. Biotechnol Lett 5:12950-12960

Jazwa A, Szpyrka E, Sadło S (2009) Disappearance of pendimethalinin soil and its residue in ripe fennel. J Central European Agric 10(2):153-158

Kaur R, Gill BS (2012) Analysis of herbicide residues in celery seeds. Indian J Ecol 39(2):258-260

Kloepper JW (1994) Plant growth-promoting rhizobacteria (other systems). In: Okon Y (ed) Azospirillum/plant associations. CRC Press, Boca Raton, FL, pp 137-166

Kothari SK, Singh CP, Singh K (2002) Weed control in rose-scented geranium (Pelargonium spp). Pest Manag Sci 58(12):1254-1258

Kulshrestha G, Singh SB, Gautam KC (1995) Residues of fluazifop-P-butyl following application to soybean. BECT 55(2):276-282
Kumar A, Tewari AN (2004) Efficacy of pre-and post-emergence herbicides in summer blackgram (Vigna mungo L.) Indian. J Weed Sci 36:73-75

Kumbar B, Prasad TR, Somashekar KS, Hatti V, Ullash MY, Madhukumar V (2014) Evaluation of doses of new herbicide fluazifop-p-butyl 13.4 EC for grassy weeds management in irrigated groundnut. The Bioscan 9:1135-1137

Lebuhn M, Heulin T, Hartmann A (1997) Production of auxin and other indolic and phenolic compounds by Paenibacillus polymyxa strains isolated from different proximity to plant roots. FEMS Microbiol Ecol 22:325-334

Mahfouz SA, Sharaf Eldin MA (2007) Effect of mineral vs. biofertilizer on growth, yield, and essential oil content of fennel (Foeniculum vulgare Mill). Int Agrophys 21(4):361-366

Mahmoud SM, Mohamed SH, El-Desoky MM, Abd-Alla MH (1996) Residual effect of application of some pesticides on growth and nodulation of soybean. Assuit J Agric Sci 27(3):83-91

Mali AL, Suwalka SN (1987) Studies on weed control in fenugreek. Indian J Agron 32:188-189

Meena SS, Mehta RS (2009) Effect of weed management practices on weed indices, yield and economics of fennel (Foeniculum vulgare Mill.). Indian J Weed Sci 36(41):195-198

Michaud MH, Gosselin A, Tremblay N, Benoit DL, Bélanger A, Desroches B (1993) Effect of a herbicide and two plant densities on the yield of medicinal plants grown in Quebec (Canada). Acta Hortic 331:311-318

Mohamed SM, El-Ghait EA, El Shayeb NS, SA, Ghatas YA, Shahin AA (2016) Effect of some fertilizers on improving growth and oil productivity of basil (Ocimum basilicum L.) CV. Genovese plant. Egypt J Appl Sci 30(6):384-399

Ngow Z, Chynoweth RJ, Gunnarsson M, Rolston P, Buddenhagen CE (2020) A herbicide resistance risk assessment for weeds in wheat and barley crops in New Zealand. PLoS ONE 15(6):e0234771. https://doi.org/10.1371/journ al.pone.0234771

Pank F, Hannig HJ, Hauschild J, Zygmunt B (1980) Chemical weed control in the cropping of medicinal plants. Part 1: Valerian (Valeriana officinalis L.). Pharmazie 35:115-119

Patel SM, Amin AU, Patel SP, Patel JA (2017) Influence of weed management practices on weeds, yield, quality and economics of fennel. Int J Seed Spices 7(2):45-49

Pickett KM, Zheljazkov D (2017) Screening of preemergence and postemergence herbicides for weed control in dill (Anethum graveolens), fennel (Foeniculum vulgare), coriander (Coriandrum sativum) and basil (Ocimum basilicum). In Jeliazkov (Zheljazkov) and Cantrell: Medicinal and aromatic crops: Production, phytochemistry, and utilization. ACS Symposium Series; American Chemical Society, Washington, DC. https://doi.org/10. 1021/bk-2016-1218.ch008

Rahimi A, Moghaddam SS, Ghiyasi M, Heydarzadeh S, Ghazizadeh K, PopovicDjordjević, J. (2019) The Influence of chemical, organic and biological fertilizers on agrobiological and antioxidant properties of Syrian cephalaria (Cephalaria syriaca L.). Agriculture 9:122

Rajeswara Rao BR, Rajput DK, Sastry KP, Bhattacharya AK, Patel RP, Ramesh S (2007) Effect of crop-weed mixed distillation on essential oil yield and composition of five aromatic crops. J Essent Oil Bear Plants 10(2):127-132

Reinhardt EL, Ramos PL, Manfio GP, Barbosa HR, Pavan C, Filho CAM (2008) Molecular characterization of nitrogen-fixing bacteria isolated from Brazilian agricultural plants at also Paulo state. Braz J Microbiol 39:414-422

Sachin DN (2009) Effect of Azotobacter chroococcum (PGPR) on the growth of bamboo (Bambusa bamboo) and maize (Zea mays) plants. Biofrontiers 1:24-31

Sakr MT, Ibrahim HM, Shalan MN, Shehata AAA (2014) Efficacy of some organic and bio-fertilizers on growth, yield and its quality of sweet basil (Ocimum bailicum L.) plants. J Plant Prod Mansoura Univ 5(7):1209-1224

Saxena J, Geetika R, Mrinal P (2013) Impact of addition of biochar along with Bacillus sp. on growth and yield of French beans. Sci. Hortic. 162:351-356. https://doi.org/10.1016/j.scienta.2013.08.002

Sefidkon F (2012) Effects of organic fertilizers on essential oil content and composition of some aromatic plants. In: Proceedings of National Congress on Medicinal Plants. Kish Island

Shabana EF, Khalil Z, Kobbia IA, Zaki FT (1991) Amino acid content and transaminases in Anabeana oryzae and Nostoc muscorum as affected by some pesticides. Egypt J Physiol Sci 15(1-2):21-30

Singh G, Virk H, Sharma P (2017) Efficacy of pre-and post-emergence herbicides for weed control in greengram. Indian J Weed Sci 49(3):252-255 
Singh G, Maurya S, de Lampasona MP, Catalan C (2006) Chemical constituents, antifungal and antioxidative potential of Foeniculum vulgare volatile oil and its acetone extract. Food Cont 17:745-752

Soliman IE, Morsi AR, Khaffagy EA (2015) Effect of competitive abilities of some soybean genotypes, plant densities and weed control treatments on soybean (Glycine max L.) and its associated weeds. J Plant Product Mansoura Univ 6(8):1413-1429

Sondhia S (2014) Herbicides residues in soil, water, plants and non-targeted organisms and human health implications: an Indian perspective. Indian J Weed Sci 46(1):66-85

Starratt AN, Lazarovits G (1999) Herbicide-induced disease resistance and associated increases in free amino acid levels in melon plants. Canad J Plant Path 21(1):33-36

Taghavi S, Garafola C, Monchy S, Newman L, Hoffman A, Weyens N, Barac T, Vangronsveld J, van der Lelie D (2009) Genome survey and characterization of endophytic bacteria exhibiting a beneficial effect on growth and development of poplar trees. Appl Environ Microbiol 75:748-757

Talaat NB (2019) Effective microorganisms: an innovative tool for inducing common bean (Phaseolus vulgaris L.) salt-tolerance by regulating photosynthetic rate and endogenous phytohormones production. Sci Hortic 250:254-265

Talaei GH, Vazirimehr MR, Shahgoli H, Shirmohammadi E, Sabbagh E, Rigi K (2014) Influence of biological and chemical nitrogen fertilizers on grain yield and yield components of fennel (Foeniculum vulgare Mill). Int J Biosci 4(9):206-211. https://doi.org/10.12692/ijb/4.9.206-211

Upadhyay RK, Baksh H, Patra DD, Tewari SK, Sharma SK, Katiyar RS (2011) Integrated weed management of medicinal plants in India. Int J Med Aromat Plants 1(2):51-56
Voevodin AV, Borisenko LA (1981) The use of herbicides for sequential of perennial and annual weeds in vegetable crops and the significance of this method for environment protection. Hort Int Abst 54:3875

Wall DA, Friesen GH (1986) The effect of herbicides and weeds on the yields and composition of dill (Anethum graveolens L.) oil. Crop Prot 5:137-142

Waller RA, Duncan DB (1969) A Bayes rule for the symmetric multiple comparisons problem. J Am Stat Assoc 64(324):1484-1503

Wilfred K, Dzomeku I, Joseph K (2020) Efficacy of pre-emergence and postemergence herbicides for weed management in groundnut (Arachis hypogaea L.) production in Guinea Savannah. Int J Sci Res 8(1):263-276

Yoshida S (1969) Biosynthesis and conversion of aromatic amino acids in plants. Ann Rev Plant Physiol 20:41-62

Yousefi AR, Rahimi MR (2014) Integration of soil-applied herbicides at the reduced rates with physical control for weed management in fennel (Foeniculum vulgare Mill.). Crop Prot 63:107-112

Zheljazkov V, Zhalnov I (1995) Effect of herbicides on yield and quality of Coriandrum sativum L. J Essent Oil Res 7:633-639

Zheljazkov VD (1998) Essential oil crops. In: Pehlivanov M, Mosikov G, Yankov B, Terziev J, Zheljazkov VD, Yantcheva H (eds) Plant production edition 1. Academic Edition of Higher Institute of Agriculture Plovdiv, Plovdiv, pp 279-340

\section{Publisher's Note}

Springer Nature remains neutral with regard to jurisdictional claims in published maps and institutional affiliations.

\section{Submit your manuscript to a SpringerOpen ${ }^{\circ}$ journal and benefit from:}

- Convenient online submission

- Rigorous peer review

- Open access: articles freely available online

- High visibility within the field

- Retaining the copyright to your article

Submit your next manuscript at $\boldsymbol{\nabla}$ springeropen.com 